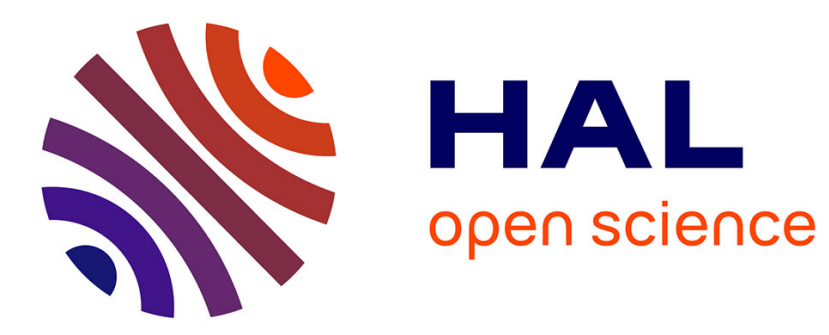

\title{
Clostridium perfringens related spleen gangrene
}

\author{
Guillaume Dumas, Jacques Tankovic, Naïke Bige, Eric Maury
}

\section{To cite this version:}

Guillaume Dumas, Jacques Tankovic, Naïke Bige, Eric Maury. Clostridium perfringens related spleen gangrene. Intensive Care Medicine, 2017, 10.1007/s00134-017-4899-5 . hal-01592626

\section{HAL Id: hal-01592626 \\ https: / hal.sorbonne-universite.fr/hal-01592626}

Submitted on 5 Oct 2017

HAL is a multi-disciplinary open access archive for the deposit and dissemination of scientific research documents, whether they are published or not. The documents may come from teaching and research institutions in France or abroad, or from public or private research centers.
L'archive ouverte pluridisciplinaire HAL, est destinée au dépôt et à la diffusion de documents scientifiques de niveau recherche, publiés ou non, émanant des établissements d'enseignement et de recherche français ou étrangers, des laboratoires publics ou privés. 


\title{
Clostridium perfringens related spleen gangrene
}

\author{
Authors: \\ Guillaume Dumas ${ }^{1,3}$, Jacques Tankovic ${ }^{2}$, Naike Bigé ${ }^{1}$, Eric Maury 1,3,4 \\ ${ }^{1}$ Service de Réanimation Médicale, Hôpital Saint-Antoine Assistance Publique - Hôpitaux de Paris \\ ${ }^{2}$ Service de Microbiologie, Hôpital Saint-Antoine Assistance Publique - Hôpitaux de Paris \\ Paris, F-75012, France \\ ${ }^{3}$ Université Pierre et Marie Curie \\ ${ }^{4}$ I UMR S 1136, INSERM et Sorbonne Universités, UPMC Univ Paris 06, Paris, F-75012, France
}

\section{Corresponding author:}

Eric Maury

Service de Réanimation Médicale,

Hôpital Saint-Antoine,

Assistance Publique - Hôpitaux de Paris,

Paris, F-75012, France; Tel: + 33149282315, Fax: +33149282692;

e-mail: eric.maury@aphp.fr

\section{Financial support: None}

Conflict of interest: The authors have no conflict of interest to declare regarding the material discussed in the manuscript.

\section{Authors' contribution:}

G. Dumas and E.Maury wrote the manuscript; G. Dumas, E.Maury, J. Tankovic and N. Bigé collected the data. Words count: 99

Key words: Splenic necrosis, Clostridium perfringens 


\section{Text:}

A 48-year old man with no previous medical history was admitted to the intensive care unit for febrile dyspnea and abdominal pain. Abdominal palpation disclosed pain of the left flank without guarding. There was no argument for disseminated intravascular coagulation or intravascular hemolysis. Echocardiography noticed enlarged right ventricle without argument for patent foramen ovale. Thoracoabdominal CT scan revealed bilateral pulmonary embolism, non-occlusive thrombi of coeliac, superior mesenteric and splenic arteries with an intra-splenic gaseous collection (figure 1). No peritoneal effusion was noticed during laparoscopic splenectomy, but surgeons reported a foul-smelling odor. Splenic sample were positive for Clostridium perfringens.

\section{Figure legend:}

Abdominal CT scan of a 48-year old man with left flank pain and fever.

Panel 1a: voluminous splenic infarct with intra splenic gaseous collection (C) and partial thrombus of superior mesenteric artery.

Panel 1b and 1c: Maximum Intensity Projection (MIP) reconstructed image demonstrates thrombosis (arrows) of celiac trunk (1b) and splenic artery (1c). Splenic collection (C) is also demonstrated. 